\title{
Physico-chemical and Bacteriological Assessment of Groundwater from Peri-urban Area of Douala - Cameroon
}

\author{
Tatou Rel Dechangue ${ }^{1, ~ *, ~ K a m g a n g ~ K a b e y e n e ~ V e r o n i q u e ~}{ }^{2}$, Kengni Lucas ${ }^{3}$ \\ ${ }^{1}$ Department of Earth Sciences, Faculty of Sciences, University of Maroua, Maroua, Cameroon \\ ${ }^{2}$ Department of Biological Sciences, Higher Teachers Training College, University of Yaounde I, Yaounde, Cameroon \\ ${ }^{3}$ Department of Earth Sciences, Faculty of Sciences, University of Dschang, Dschang, Cameroon
}

Email address:

rtatou@yahoo.fr (T. R. Dechangue)

${ }^{*}$ Corresponding author

\section{To cite this article:}

Tatou Rel Dechangue, Kamgang Kabeyene Veronique, Kengni Lucas. Physico-chemical and Bacteriological Assessment of Groundwater from Peri-urban Area of Douala - Cameroon. American Journal of Environmental Protection. Vol. 10, No. 5, 2021, pp. $104-110$. doi: 10.11648/j.ajep.20211005.11

Received: August 4, 2021; Accepted: September 4, 2021; Published: September 15, 2021

\begin{abstract}
The physicochemical characterization of water of the peri-urban area of Douala city was carried out from 04 springs and 21 wells in February 2013 and August 2013 corresponding to the dry season and the rainy season respectively. For bacteriological analyzes, thirteen water points were sampled, including 4 sources, 08 wells in the rainy and dry season. All the water points yielded $\mathrm{pH}$ values below 7,0 and were classified as acidic water. Electrical conductivity ranged between 44.30$483 \mu \mathrm{m} / \mathrm{cm}$ and then waters are poor mineralized. The relative abundance of major ions (mg/l) was $\mathrm{Ca}^{2+}>\mathrm{Na}^{+}>\mathrm{K}^{+}>\mathrm{Mg}^{2+}$ for cations in dry season whereas and $\mathrm{Na}^{+}>\mathrm{K}^{+}>\mathrm{Ca}^{2+}>\mathrm{Mg}^{2+}$ in the rainy season. For the anions, $\mathrm{HCO}_{3}>\mathrm{Cl}->\mathrm{SO}_{4}{ }^{2-}>\mathrm{NO}_{3}{ }^{-}$in the dry season whereas in the rainy season $\mathrm{HCO}_{3-}>\mathrm{Cl}->\mathrm{NO}_{3}{ }^{-}>\mathrm{SO}_{4}{ }^{2-}$. Major ion concentrations were within the WHO guidelines for drinking water, but a few points have a concentrations below the WHO limits. Main water types in the both seasons were $\mathrm{Ca}-\mathrm{Mg}-\mathrm{HCO}_{3}$ and $\mathrm{Ca}-\mathrm{Mg}-\mathrm{Cl}$. Bacteriological analysis revealed that all water points sampled during the rainy season and some (67\%) during dry season contain feacal contamination control germs. Bacteriological contamination of the water is of human and animal origin. Human origin is linked outflow from latrines used by the population. The spring and well waters analysed are not suitable for drinking and domestic purposes except two springs in the dry season.
\end{abstract}

Keywords: Physicochemistry, Bacteriology, Groundwater, Periurban, Douala, Cameroon

\section{Introduction}

Water, an essential natural resource for all life, is unevenly distributed over the surface of the earth. Fresh water, which is that directly used for various human activities, must be preserved in quantity and quality. In the peri-urban areas of large cities in most sub-Saharan countries, groundwater is the main source of drinking water. However, collected water may contain elements that can have undesirable effects on health, such as pathogenic microorganisms, undesirable substances or even toxic substances [1]. It is therefore necessary to have better knowledge of the water resources consumed by the population. Numerous studies carried out in Cameroon and particularly in the city of Douala, have made it possible to characterize well water for domestic use in densely populated neighborhoods and to highlight the sources of pollution from these wells. The results of these studies show chemical and bacteriological pollution of anthropogenic origin [2-5]. The use of these waters represents a danger for the population. Cases of cholera, diarrhea, dysentery, typhoid fever, malaria and skin diseases have been reported in many households in Douala $[6,7]$. In the city of Douala, the rate of household connection to the drinking water network is low, around $30 \%$ [8]. To obtain drinking water, many people lean towards wells, springs and boreholes. To date, the peri-urban areas of the city of Douala do not have significant data on the quality of groundwater. Water has no quality in itself, except in the context for which it is used. Its quality depends on its use under specific conditions. Indeed, water intended for human consumption would not have the same quality standards as that of water for industrial or irrigation use. Hydrochemical 
and bacteriological variability is studied in order to assess the potential of the resource and to identify the water quality issues in the peri-urban districts of the Douala city.

Presentation of the study area

The area concerned by this study is located between latitudes $4^{\circ} 00^{\prime} 29$ "and $4^{\circ} 02^{\prime} 08^{\prime \prime N o r t h}$; longitudes $9^{\circ} 46^{\prime} 11^{\prime \prime}$ and $9^{\circ} 48^{\prime} 06^{\prime} \mathrm{E}$. It covers an area of approximately $5000 \mathrm{~m}^{2}$ (Figure 1). The hydrographic network is sparse fed by the main river, which is the Kambo, and a few tributaries. The activities practiced are mainly small trade, cattle and poultry farming, market gardening. In this area, the population density is between 26 and 150 inhabitants per $\mathrm{km}^{2}$ [9]. Average annual precipitation is very abundant around $3664.86 \mathrm{~mm}$ [10]. Most of the soils encountered are of the ferralitic type [11-13]. They have a sandy to sandy-clay texture more or less leached, favorable to rainwater infiltration. The hydromorphic soils are formed from recent or sub-recent deposits. These can be gley soils belonging to the group of marsh soils rich in organic matter [14] or pseudogley soils.

The rocks found in the study area are part of the sedimentary formations that make up the Douala basin [15]. Waters studied capture the Mio Pliocene aquifer consisting of alternating clay and sands with gravel transitions.

\section{Methodology}

Water sample collection campaigns for the various physicochemical analyzing took place in two phases. Twenty five water samples were collected from four sources and 21 wells in February 2013 and August 2013 corresponding to the dry season and the rainy season respectively.

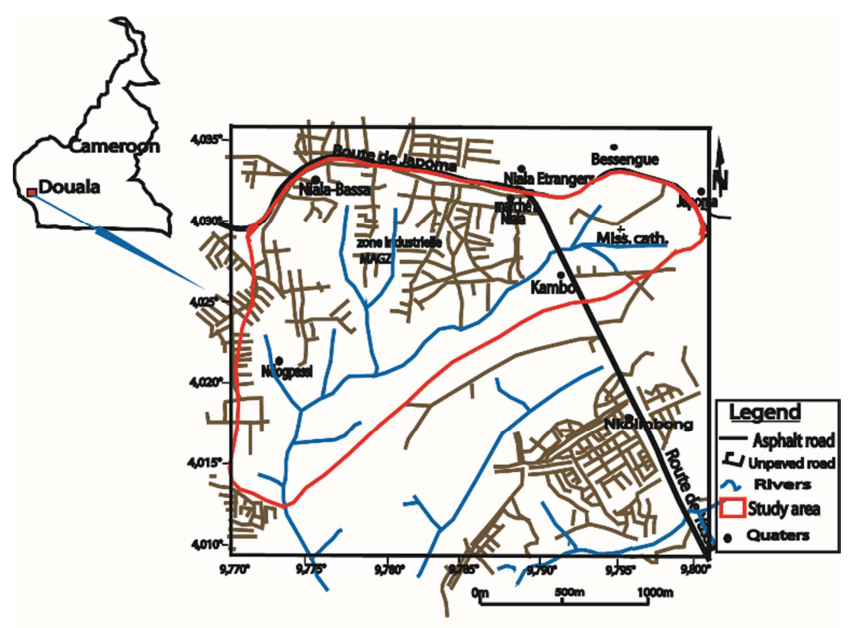

Figure 1. Location of study area.

Samples were carried out in $500 \mathrm{ml}$ PVC bottles at the request of the laboratory while respecting the recommendations of Rodier [16]. Physical parameters (temperature, $\mathrm{pH}$, conductivity) were measured in the field using a multiparameter. Chemical analyzes $\left(\mathrm{Ca}^{2+}, \mathrm{Mg}^{2+}, \mathrm{Na}^{+}\right.$, $\mathrm{K}^{+}, \mathrm{Cl}^{-}, \mathrm{HCO}_{3}{ }^{2-}, \mathrm{SO}_{4}{ }^{2-}, \mathrm{NO}_{3}{ }^{-}, \mathrm{Fe}$ ) were carried out at the LASPEE laboratory of the Institute of Agronomic Research for Development (IRAD) of Yaounde. Major cations were analyzed using a flame atomic absorption spectrophotometer. Chlorides and bicarbonates were analyzed by titration and sulfates and nitrates by colorimetry. The research and enumeration of bacteriological germs (coliforms and faecal streptococci) took place at the WWRU laboratory of the University of Yaounde I. Method used is the filter membrane using an appropriate support under sterile conditions [16].

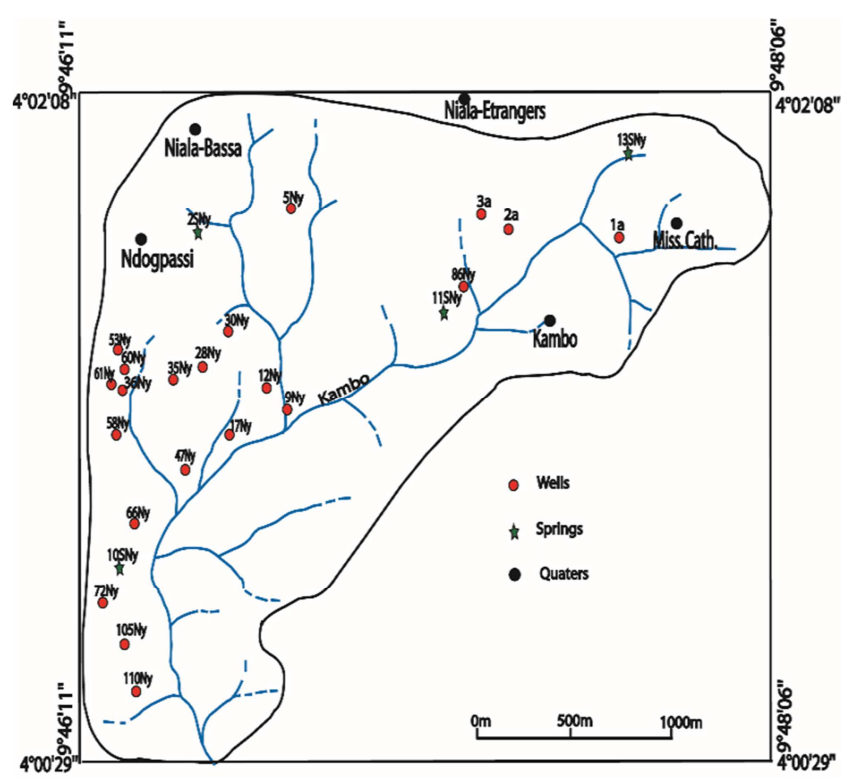

Figure2. Location of sample points.

\section{Results and Discussion}

\subsection{Physical Parameters}

The $\mathrm{pH}$ measured in the water sampled is in the range of 4.18 to 6.67 (mean=5.05) in dry season and of 4.08 to 6.48 (mean=5.29) in rainy season. $\mathrm{pH}$ of all samples makes it possible to attribute an acidic character to these waters. $\mathrm{pH}$ tends towards neutrality in some wells. Conductivity varies between 48.70 and $430 \mu \mathrm{S} / \mathrm{Cm}$ (mean181.13) in dry season and between 44.30 and $483 \mu \mathrm{S} / \mathrm{Cm}$ for an average of 214.95 $\mu \mathrm{S} / \mathrm{Cm}$ in rainy season. This low conductivity shows that waters are poor mineralized.

\subsection{Cations}

Calcium is the most represented cation. It varies from 2.83 to $74.90 \mathrm{mg} / \mathrm{l}$ for an average of 17.95 in dry season and from 0.2 to 23.85 for an average of 6.65 in rainy season. Magnesium is present in the water in low proportions. Its overall content ranges from 0.51 to $8.70 \mathrm{mg} / 1$ (mean=2.91) in dry season and from 1.59 to 2.36 (mean=6.98) in rainy season. Sodium ranges from 1.33 and $14.96 \mathrm{mg} / \mathrm{l}$ (mean $7.21 \mathrm{mg} / \mathrm{l}$ ) in dry season and from 1.89 to 22.11 for an average of 9.96 in rainy season. In these waters, sodium represents the second abundant cation. Potassium has levels close to those of sodium in all waters and varies between 0 and $14.62 \mathrm{mg} / \mathrm{l}(\mathrm{mean}=4.76)$ in dry season and from 0.6 to $23.03($ mean $=5.78)$ in rainy season. 


\subsection{Anions}

In the water samples analyzed, bicarbonate contents vary from 0 to $286.7 \mathrm{mg} / \mathrm{l}$ (average 28.86) in dry season and from 0.97 to 256.85 (average of 43.81) in rainy season. For chlorides, contents are between 0 and $209.45 \mathrm{mg} / \mathrm{l}$ (mean=16.81) in dry season and from 0 to 26.98 (mean=8.98) in rainy season. In low proportions, the nitrate contents are between 0 to $3.61 \mathrm{mg} / 1$ (mean 1.14) in dry season and between 0.31 and 25.78 (mean=8.64) in rainy season. Sulphates are the weakest represented anions, their contents range from 0 to $16.4 \mathrm{mg} / \mathrm{l}($ mean=2.43) in dry season and from 0.41 to 11.81 (mean=4.92) in rainy season.

The iron contents vary between 0 and $19.42 \mathrm{mg} / 1$ (average $=3.43$ ) in dry season and between 0 and 1.017 (mean $=0.15$ ) in rainy season. Iron is abundant in some water points exclusively in the dry season. In fact, Iron is a fairly abundant element in rocks (a few percentage) in the form of silicates, oxides and hydroxides, carbonates and sulphides. Presence of iron has been reported in groundwater in the Douala basin [17-18]. However, contents rarely exceed 1 $\mathrm{mg} / \mathrm{l}$ in water. Several hypotheses are put forward to justify the presence of this ion in the water. In the soil profiles (between 3 and $15 \mathrm{~m}$ ) in the study area as well as in other localities of Douala, there is a level of iron accumulation [13]. which leaching of would lead it towards the waters especially since most of the wells are shallow. Significant levels of iron were found in borehole water in the Tiassalé region in Côte d'Ivoire [19], in the waters of the Morsott-Laouinet aquifer complex in south-eastern Algeria [20], also in groundwater in urban areas southwest of Brazzaville [21]. The high grades are linked to the geological context of the area. In the sedimentary materials of the Douala sub-basin, pyrite deposits have been detected [22, 23]. This suggests that abundance of iron in the waters of the upstream Kambo watershed reflects the probable existence of pyrite in the sediments. Otherwise, the static level of the water would coincide with the levels of accumulation leading to excessive iron levels in the water. In the rainy season, the iron content drops considerably in the water. This can be explained by the increase in static levels leading to a high water dilution. This justifies that the origin of this iron is intimately linked to the geochemical content of the site where the sample is taken.

Table 1. Result of physico chemical parameters.

\begin{tabular}{llllllll}
\hline \multirow{2}{*}{ Paramètres } & Dry season & & & Rainy season & OMS \\
\cline { 2 - 6 } & MIN & MAX & MOY & MIN & MAX & MOY & Standard \\
\hline $\mathrm{pH}$ & 4,18 & 6,65 & 5,05 & 4,08 & 6,48 & 5,23 & $6,5-8,5$ \\
$\mathrm{C} . \mathrm{E} .(\mu \mathrm{S} / \mathrm{cm})$ & 48,7 & 430 & 181,13 & 44,3 & 483 & 214,95 & $<300$ \\
$\mathrm{Ca}^{2+}(\mathrm{mg} / \mathrm{l})$ & 2,83 & 74,9 & 17,95 & 0,2 & 23,85 & 6,65 & 250 \\
$\mathrm{Mg}^{2+}(\mathrm{mg} / \mathrm{l})$ & 0,51 & 8,7 & 2,91 & 1,59 & 21,36 & 6,98 & 50 \\
$\mathrm{Na}^{+}(\mathrm{mg} / \mathrm{l})$ & 1,33 & 14,96 & 7,21 & 1,89 & 22,11 & 9,96 & 200 \\
$\mathrm{~K}^{+}(\mathrm{mg} / \mathrm{l})$ & 0 & 14,62 & 4,76 & 0,6 & 23,03 & 5,78 & 12 \\
$\mathrm{NO}_{3}(\mathrm{mg} / \mathrm{l})$ & 0 & 3,61 & 1,14 & 0,31 & 25,78 & 8,64 & 50 \\
$\mathrm{Cl}^{-}(\mathrm{mg} / \mathrm{l})$ & 0 & 209,45 & 16,81 & 0 & 26,98 & 8,98 & 250 \\
$\mathrm{SO}_{4}{ }^{2-}(\mathrm{mg} / \mathrm{l})$ & 0 & 16,21 & 2,43 & 0,41 & 11,81 & 4,92 & 250 \\
$\mathrm{HCO}_{3}^{-}(\mathrm{mg} / \mathrm{l})$ & 0 & 286,7 & 28,86 & 0,97 & 256,2 & 43,81 & 250 \\
$\mathrm{Fe}(\mathrm{mg} / \mathrm{l}) *$ & 0 & 19,42 & 3,43 & 0 & 1,017 & 0,15 & 0,3 \\
\hline
\end{tabular}

\subsection{Hydrochemical Facies}

Interpretation of the values of different physicochemical parameters shows that, whatever the sampling period, two main facies are illustrated for groundwater in the study area. It is the chlorinated and sulphated calcium and magnesian facies and calcium and magnesian bicarbonate facies. The predominance of calcium ions gives them the calcium character. However, Piper's diagram (figure 3), show a migration to the sodium and potassium pole for samples taken in August corresponding to the rainy season. The obtained facies agree is obtained by Tatou [24] who dealt in detail with a larger number of samples in this area.

\subsection{Bacteriological Parameters}

In all analyzed samples in the rainy season, rate of feacal coliforms (FC) varies between 15 and $600 \mathrm{CFU} / 100 \mathrm{ml}$ for an average of 224.83 while rate of streptococci (FS) vary between 10 and $270 \mathrm{CFU} / 100 \mathrm{ml}$ for an average of 110.33 . No sample is exempt from those germs which are evidence of feacal pollution (Table 2). FC/FS ratio is greater than 4 for two water points and others have values between 0.7 and 4 .

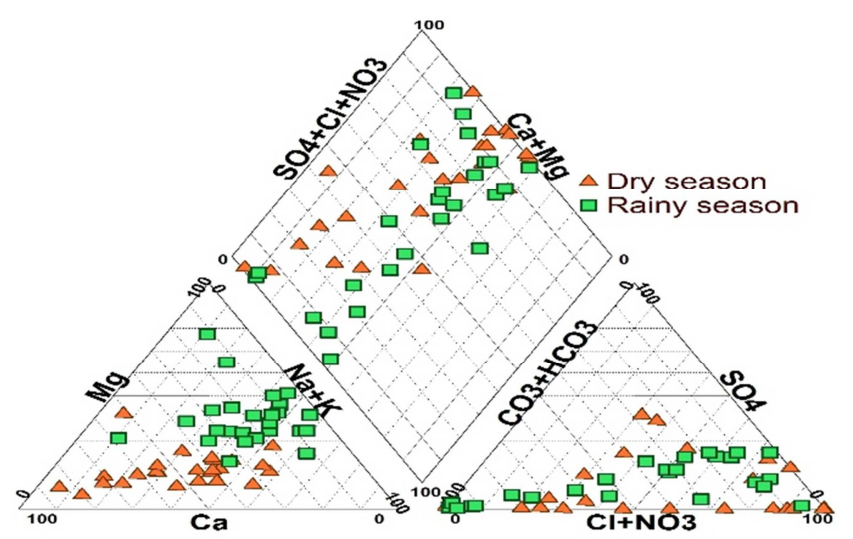

Figure 3. Piper diagram for analysed samples.

For the dry season, feacal coliforms content are from 0 to $320 \mathrm{UFC} / 100 \mathrm{ml}$ for an average of 85.42 . Feacal streptococci range from 0 to $130 \mathrm{CFU} / 100 \mathrm{ml}$ for an average of 31.25 . A single well $(35 \mathrm{Ny})$ has the highest values. Two sources (10SNy and 11SNy) are free of feacal germ during this dry 
season sampling. In other samples, the number of feacal streptococci is lower than the number of feacal coliforms. Concerning the FC/FS ratio, six (6) wells have values between 0.7 and 4 , only one well with a value greater than 4 and one with a value less than 0,7 . The rate of feacal germs counted in dry season is overall lower than the rate obtained in rainy season.

Table 2. Results of bacteriological analyses.

\begin{tabular}{|c|c|c|c|c|c|c|c|c|c|}
\hline \multirow{2}{*}{ code } & & \multicolumn{4}{|c|}{ Rainy season. } & \multicolumn{4}{|c|}{ Dry season } \\
\hline & & FC & FS & FC/FS & origin & FC & FS & FC/FS & origin \\
\hline $5 \mathrm{NY}$ & W & 460 & 170 & 2,71 & mixte & 200 & 74 & 2,7 & mixed \\
\hline $12 \mathrm{NY}$ & W & 50 & 12 & 4,17 & Human & 4 & 8 & 0,5 & Animal \\
\hline $35 \mathrm{NY}$ & W & 400 & 96 & 4,17 & Human & 320 & 130 & 2,46 & Mixed \\
\hline $47 \mathrm{NY}$ & W & 600 & 270 & 2,22 & Mixed & 280 & 90 & 3,11 & mixed \\
\hline $58 \mathrm{ND}$ & W & 320 & 260 & 1,23 & Mixed & 2 & 0 & 0 & \\
\hline $105 \mathrm{ND}$ & W & 28 & 12 & 2,33 & Mixed & 0 & 7 & 0 & \\
\hline $2 \mathrm{a}$ & W & 30 & 10 & 3 & Mixed & 33 & 10 & 3,3 & Mixed \\
\hline $76 \mathrm{Ny}$ & W & 180 & 100 & 1,8 & Mixed & 101 & 37 & 2,73 & mixed \\
\hline 10SNy & $\mathrm{S}$ & 75 & 44 & 1,7 & Mixed & 0 & 0 & 0 & \\
\hline $2 \mathrm{SNy}$ & S & 220 & 160 & 1,37 & Mixed & 72 & 13 & 5,54 & Human \\
\hline $11 \mathrm{SNy}$ & $\mathrm{S}$ & 320 & 180 & 1,78 & Mixed & 0 & 0 & 0 & \\
\hline $13 \mathrm{SNy}$ & $\mathrm{S}$ & 15 & 10 & 1,5 & Mixed & 13 & 6 & 2,17 & mixed \\
\hline MAX & & 600 & 270 & 4,17 & & 320 & 130 & 5,54 & \\
\hline MIN & & 15 & 10 & 1,23 & & 0 & 0 & 0 & \\
\hline MOY & & 224,83 & 110,33 & 2,33 & & 85,42 & 31,25 & 1,87 & \\
\hline
\end{tabular}

$\mathrm{W}=$ wells; $\mathrm{S}=$ springs, $\mathrm{FC}=$ Feacal coliform, FS Feacal streptococci

\subsection{Assessment of Hydrochemical Potability}

Based on hydrochemistry, all water points sampled have a $\mathrm{pH}$ below 7.0 during all seasons. The results of the hydrochemical facies show that waters of the wells are subject to natural mineralization. Low mineralization observed reflects the nature of geological formations in which these waters circulate mainly composed of secondary minerals such as sands and clays [10]. However, note that, water consumed by humans must contain sufficient minerals to ensure their health according to the WHO standard. Water intended for consumption must have a minimum of $60 \mathrm{mg} / 1$ for total hardness, either $10 \mathrm{mg} / 1$ for magnesium and $20 \mathrm{mg} / 1$ for calcium [25]. Water with calcium and magnesium deficiency presents a health risk [26]. Dissanayake [27]. found a negative correlation between hardness and several forms of cardiovascular disease and leukemia in Siri Lanka. Similarly, COMA [28] also found an inverse relationship between water hardness and cardiovascular disease. This implies that people who consume water with low calcium (less than 20mg/l) and magnesium (less than 10mg/l) are likely to suffer from these diseases. Water points sampled have low levels of calcium and magnesium, indicating that populations consuming these waters are at risk of cardiovascular disease.

Iron is essential for human health in trace conditions. The presence of iron in drinking water, do not pose any real risks to human health. Thus, the nuisance of iron in the water is [29]: the neutralization of some disinfectants due to iron oxidation; the distribution of rust-colored water, which is aesthetically unattractive to the consumer, and which can stain laundry and sanitary; the metallic taste of water; the risk of corrosion of pipes due to the development of microorganisms (ferrobacteria). Based on the physicochemical characteristics of raw water, the elimination of iron in the water is done through biological processes such as biological treatment and physico-chemical treatment [30].

\subsection{Bacteriological Potability Assessment}

All water points sampled during the rainy season and some $(67 \%)$ during dry season contain feacal contamination control germs. This indicates that, waters receive contaminated water. High values obtained in rainy season range from 10 to $600 \mathrm{CFU} / 100 \mathrm{ml}$ for $\mathrm{CF}$ and from 10 to 270 CFU/100 ml for SF. Similar results were obtained by Eneke [4] in certain peri-urban areas of the city of Douala. Similar results to those in the study area were also recorded in spring's waters of the western mountainous Côte d'Ivoire (village of Mangouin-Yrongouin) by Ahoussi [31]. Contamination of these waters may result from the leaching of microorganisms by rainwater that seeps into the soil and reaches the water table without being effectively filtered [32].

The sources of pollution are determined from the ratio of feacal coliforms to feacal streptococci [33-36]. According to those authors, when ratio ( $\mathrm{FC} / \mathrm{FS})$ is greater than 4 , the pollution is of human origin, where it is less than 0,7 , the pollution have animal origin. Theoretically according to the same authors, where the ratio is between 0.7 and 4 , pollution is both of animal and human origin.

FC/FS ratio between 0.7 and 4 in the majority $(83 \%$ in the rainy season and $50 \%$ in the dry season) of the water samples analyzed (Table 2) shows that bacteriological contamination of the water is of human and animal origin. Human origin is linked outflow from latrines used by the population as noted in other locations in Douala $[3,18]$. Animal pollution would come from animal waste. In fact, in the study area, breeding (poultry farming, pig farming) is one of the most practiced activities by the population. Thus, discharges from this 
livestock farming would be a major factor in groundwater contamination [37] following the infiltration of rain water that drains waste to the soil depths. This is consistent with the increase in nitrate levels in the water during the rainy season. Influence of anthropogenic activities on water quality has been observed in the Baikunthpur region, the Rewa District, Madhya and Pradesh in India [38].

Feacal coliforms are witnesses of recent feacal contamination whereas streptococci show ancient feacal contamination [39]. The presence of these germs in all samples collected during the rainy season indicates a mixture between recent and ancient feacal contamination. However, in dry season, $67 \%$ of samples contain feacal coliforms and streptococci, their contamination is both recent and ancient. One point (105ND) is marked by an ancient contamination, which reflected the absence of feacal coliforms and another point (58ND) is marked by recent pollution, which reflected by the absence of feacal streptococci. Two wells (12Ny and 35Ny) in the rainy season and one spring in the dry season show a sign of human contamination $(\mathrm{CF} / \mathrm{SF}=4.17)$. This would result from a larger number of latrine around these sampling points. Only one well (12Ny) shows a sign of animal contamination $(\mathrm{CF} / \mathrm{SF}=0.5)$ in dry season, although the count of germ is quite low. This is due to a large number of feacal streptococci at this point, however, contamination is of human origin $(\mathrm{CF} / \mathrm{SF}=4.17)$ at this point in the rainy season. This seasonal variation in germ count at this point is a sign of occasional contamination. The high dispersion between waters of wells and springs reflects dispersed sources of contamination in the study area. Results obtained are in line with the less anthropogenic situation of the study area. Comparing the maximum values obtained from feacal coliforms and streptococci in the study area with those obtained from densely populated areas in Douala such as the catchment areas of Ngoua and Bobongo [40], the Bepanda1 [3], the Besseke watershed [18], it is noted that the results obtained in this work are significantly lower than those achieved. This indicates that situation in this area is not alarming and requires consideration of groundwater protection to prevent pollution.

The intensity of groundwater contamination depends on the soil type and the level of pollutants [41]. The presence of these germs in the water, even in low rate, nevertheless attests to the vulnerability of the water table in Douala. Groundwater generally appears more vulnerable as the top of the groundwater is close to the surface, as the soils above the water table is permeable and the surface origin of pollution are significant, numerous and close to the study site [32, 42]. The soils of the study area have high permeability [17], this characteristic exposes groundwater to direct contamination by infiltration of charged water. Low feacal seed values indicate low environmental pollution sources in the study area. Indeed, the low population density in the study area may explain the reduced dose of germs pollutants.

Comparing the results obtained in both seasons, water is more contaminated in rainy seasons than in dry seasons. The low number of feacal germs in the dry season is thought to be due to a decrease in the rate of infiltration in the dry season, reflected in the lower piezometric level of water table [10]. In fact, during infiltration, the water leaches the soil, training with it the germs retained towards the depths. During the high water period, piezometric surface becomes shallow and moves closer to the surface at the bottom wells that connect surface water with groundwater. Such hydraulic contact would promote groundwater contamination.

With reference to the WHO standard, a few points (10SNy, $11 \mathrm{SNy}, 105 \mathrm{ND}, 58 \mathrm{ND}$ ) are suitable for drinking water during dry season. However, during the rainy season, no water samples analyzed is recommended without any prior treatment. The presence of faecal coliforms and streptococci in excess of the WHO standard in the waters analysed presents a health risk to the population consuming them. Many authors have linked contaminated water from these two groups of bacteria to water-borne diseases [43, 44, 40]. Children aged 0-5 are the most affected population [43].

In some precarious neighborhoods of the Douala city, there has been a high incidence of water-borne diseases (dysentery, diarrhea, typhoid fever) among populations [40, 45] show that the presence of fecal coliforms of fecal streptococci in the drinking water can cause many gastrointestinal diseases, diarrhea, dysentery. Thus, drinking water containing these germs poses a serious threat to the population health [46]. Waters use in the study area requires disinfection and decantation before consumption, especially during the rainy season [47].

\section{Conclusion}

The assessment of the health quality of surface water from the shallow water in peri-urban areas has enabled us to characterize this natural resource. Most chemical quality parameters are below the WHO's drinking water standard. Well water is acidic and poorly mineralized. The majority of water points in this area of study is characterized by a predominance of calcium and magnesium chloride facies and calcium and magnesium bicarbonate facies. The rate of feacal coliforms and streptococci show that, studied water requires disinfection and decantation before consumption.

\section{References}

[1] Yao K. A. Kouassi A. M., Yao B. K., Biemi J. (2010): Hydrodynamic and hydrogeochemical characterization of cracked aquifers in the Toumodi region (center of Ivory Coast), Journal of Environmental Hydrology, Volume 18 Paper 26 December 2010.

[2] Kengni L., Tematio P, Filali Rharrassi K., Tepoule Ngueke J., Tsafack E. I., Mboumi T. L., Mounier S. (2012): Pollution of surface water and groundwater in urban areas: case of DoualaBassa industrial zone (Cameroon), Int. J. Biol. Chem. Sci. 6 (4): $1838-1853$.

[3] Djuikom E., Temgoua E., Jugnia L. B., Nola M., Baane M. (2009): Bacteriological pollution of water of the wells used by populations in the Douala Urban Community- Cameroun, International Journal of Biological and Chemical Sciences. Pub. $\mathrm{N}^{\circ}$, pp. 967-978. 
[4] Eneke T. G, Chandrasekharam D., Ayonghe N. S., Thambidurai P. (2009): Pollution characteristics of alluvial groundwater from springs and bore wells in semi-urban informal settlements of Douala, Cameroon, Western Africa, Environ Earth Sci (2010) 61: 287-298, DOI 10.1007/s12665009-0342-8.

[5] Ndjama J., Kuitcha D., Tita Margaret Awah, Kamgang Kabeyene Beyala V., Sigha Nkamdjou L., Ekodeck G. E. (2011): Specific wealth and bacterial abundance in two watersheds (Mgoua and Bobongo) of Douala, Cameroon, J A S E, firstsemester, pp 71- 83 .

[6] Assako Assako, R. J., Meva'a Abomo, D., Tchuikoua, L. B. (2005): Geographic study of the cholera epidemic in Douala or the quality of life that is tested by urban practices. Proceedings of the Symposium «Can we claim quality and well-being spaces?» IN Spaces, quality of life and well-being, Academic pressd'Angers, 307-315.

[7] Guevart E., Noeske J., Solle J., Essomba J-M, Mbondji Edjenguele, Bita A., Mouangue A., Manga B., (2006): Cholera determinant in Douala. Med. Trop. 66 (2006) 283291.

[8] CUD (2008): Development strategy for the city of Douala and its metropolitan area, Diagnostic Summary Report, 139 p.

[9] BUCREP. (2010): Final Report 3rd general population and habitat census in Cameroon. Distribution of the population living in the coastal province by Department and District. Yaounde, Cameroon, 45-47.

[10] Tatou, 2019: Assessment of groundwater quality in the Kambo-upstream watershed (Douala): hydrochemical and bacteriological approach, $\mathrm{PhD}$ thesis, University of Dschang, $189 \mathrm{p}$.

[11] Regnoult J. M. (1986): Geological summary of Cameroon. Ministry of Mines and Energy of Cameroon, Yaoundé, 119p.

[12] Ndjigui P. D., Bilong P., Nyek B., Eno Belinga S. M., Gerard M. (1999): Morphological, mineralogical and geochemical study of two laterial profiles in the Douala plain, CameroonIn geology and environment in Cameroon; Vicat J. P et Bilong P., Ed. Collection Geocam Press, Universityof Yaounde, pp 189201.

[13] Ndome Effoudou E. (2010): Mineralogy, geochemistry and geotechnical applications of the sedimentary weathering products of Douala. PhD thesis, Universityof Yaounde I, 210 p+annexes.

[14] Abata T. (2000): The Wouri estuary mangrove soils (DoualaCameroon) Master's thesis, Universityof Yaounde I, 82p.

[15] Njiké Ngaha P. R. (1984): Contribution to the geological, stratigraphic and structural study of the Atlantic basin of Cameroon. Doctorate Thesis 3rd Cycle, University of Yaounde I, $133 \mathrm{p}$

[16] Rodier J. (2009): Water analysis; Natural Water, Waste Water, Seawater. Doc., tech. 9e édn. Édition Dunod (Ed): Paris, 1600 p.

[17] Njueya Kopa A., Nono A., Likeng J. D. H. (2012): Hydrodynamic and groundwater quality in the Douala sedimentary basin (Cameroon): case of aquifers on Quaternary and Tertiary formations, Int. J. Biol. Chem. Sci. 6 (4): 18741894.
[18] Feumba R. (2015): Hydrogeology and vulnerability assessment of the water table in the Besseke basin (Douala, Cameroon), PhD thesis, University of Yaounde 1, 254p.

[19] Oga M-S, Lasm T., Yao T. K, Soro N., Saley M. B., Kouassi D., Gnamba F. (2008): Chemical characterization of the waters of fracture aquifers: case of the Tiassale region in Ivory Coast, European Journal of Scientific Research, vol. $31 n^{\circ} 1$, pp72-87.

[20] Fehdi C., Boudoukha A., Rouabhia A., Salameh E. (2009): Hydrogeochemical characterization of groundwater in the aquifer complexMorsott-El Aouinet (Region North of Tebessa, South-East Algeria). Afrique Science, 05 (2): 217-231.

[21] Matini L., Moutou J. M., Kongo-Mantono M. S. (2009): Hydrochemical assessment of groundwater in urban areas south-west of Brazzaville, Congo, Afrique Science, 05 (1) 8298

[22] Laplaine J. (1969): Mineral indices and mineral resources of Cameroon. Mines and Geology Branch Newsletter, RFC, 113115

[23] Ngon Ngon. F. N., Abomo P. S., Mbog M. B., Bitchong A. M., Mbaï J. S., Minyemeck T. V. N., Fouateu R. Y. (2015): Geological, Mineralogical and Geochemical Studies of Pyrite Deposits in the Eastern Part of Douala Sub-Basin (Cameroon, Central Africa). International Journal of Geosciences, 6, 882893.

[24] Tatou R. D., Kamgang Kabeyene V., Ewodo Mboudou G. (2017): Multivariate Statistical Analysis for the Assessment of Hydrogeochemistry of Groundwater in Upper Kambo Watershed (Douala-Cameroon), Journal of Geoscience and Environment Protection, 2017, 5, 252-264, doi.org/10.4236/gep.2017.53018.

[25] Kozisek F. (2005): Health risks from drinking demineralised water. In: Nutrients in drinking water. World Health Organization, Geneva. pp. 148-163.

[26] Rylander R., Bonevik H., Rubenowitz E. (1991): Magnesium and calcium in drinking water and cardiovascular mortality. Scan. J. Work. Env. Hea., 17, 91-94.

[27] Dissanayake C. B., Senaratne A., Weerassoriya V. R. (1992): Geochemistry of well water and cardiovascular diseases in Siri Lanka. Int. J. Environ. Stud. 19: 195-203.

[28] COMA (1994): Nutritional aspects of cardiovascular disease. Committee on Medical Aspect of Food PolicyNo. 46 (186 pp). London: HMSO.

[29] Kothari N. (1988): Groundwater, iron and manganese: an unwelcome trio; Water Engn. Manag., 2: 25-26.

[30] CREPA (1996): Deferration of drilling water-Summary of techniques successfully tested by CREPA. Technical document $\mathrm{N}^{\circ} 1$. CREPA.

[31] Ahoussi K. E., Koffi Y. B., Kouassi A. M., Soro G., Biemi J. (2013): Hydrochemical and microbiological study of spring waters of the western mountainous region ofIvory Coast: Case of Mangouin-Yrongouin village (sub-prefecture of Biankouman), Journal of Applied Biosciences 63: 4703-4719.

[32] Boutin C. (1987): Water from surface groundwater, a vital but vulnerable natural wealth. The example of rural areas in Morocco, Sci. Eau, 6 (3) Pp. 65-357. 
[33] Mara D. D. (1974): Bacteriology for sanitary engineers. Edinboroughand London, Churchill Livingstone. 209 p.

[34] Feachem R. G. (1975): An improved role for faecal coliform to faecal streptococci ratios in the differentiation between human and non-human pollution sources (Note). Water research, 9: 689-690.

[35] Sinton L. W., Donnison A. M., Hastie C. M. (1993a): Faecal streptococcias faecal pollution indicators: are view. PartI: Taxonomy and enumeration. New Zealand journal of marine and freshwater research 27: 101-115.

[36] Jagals P., Grabow W. O. K., Villiers J. C. (1995): Evaluation of indicators for assessment of human and animal faecal pollution of surface run-off. Water Science and Technology, Volume 31 N$^{\circ} 5-6$. (C) IWA Publishing. Pp 235-241.

[37] Bridgman S. A., Robertson R. M. P., Syed Q., Speed N., Andrews N. et Hunter P. R. (1995): Outbreak of Cryptosporidiosis Associated With a Disinfected Groundwater Supply. Epidemiology and Infection, 115 (3) 555-566.

[38] Tiwari R. N., Umesh Mishra (2012): Groundwater quality and pollution potential studies around Baikunthpur area, Rewa District, Madhya Pradesh, India. International Journal of Water and Environmental Engineering, Vol. 4 (12): 377-385.

[39] Trevisan D, Vansteelant J. Y., Dorioz J. M. (2002): Survival and leaching of faecal bacteria after slurry spreading on mountain hay meadows: consequences for the management of water contamination risk, Water Research, 36: 275-283.

[40] Ndjama J., Kamgang Kabeyene Beyala V., Sigha Nkamdjou L. Ekodeck G., Tita M. A (2008). Water supply, sanitation and health risks in Douala, Cameroon, African Journal of Environmental Science and Technology, 2 (12), pp. 422-429.

[41] White R. E., Dayson J. S, Haigh R. A., Jury W. A., Sposito G. (1986): A Transfer Function Model of Solute Transport Trough Soil», 2 Illustrative Applications. Water Resources Research, 22 (2) (1986) 248-254.

[42] Nola M., Njine T., Djuikom E., Sikat Foko V. (2000). Bacteria indicators dynamics in wells as influenced by well depth and well water column thickness, in Yaounde (Cameroon). African Journal of Environmental Science and Technology, 1: 82-91.

[43] Wéthé J, Radoux M., Tanawa E. (2003). Sanitation of wastewater and socio-health and environmental risks in planned habitat areas of Yaoundé (Cameroon). Vertigo 4 (1).

[44] Katte V. Y., Fonteh M. F., Guemuh G. N. (2003): Domestic water quality in urban centers in Cameroon: a case of study of Dschang in the West Province. African Water Journal, December 2003, pp. 43-54.

[45] Galaf F., Ghannam S., (2003): Contribution to the elaboration of a manual and web site on marine pollution. Master of thesis of the diploma of state engineering degree in Agronomy, Agricultural and Veterinary InstituteHassan II, Rabat.

[46] AQUACARE, (2008): Solar Disinfection of water, a pilot project in Cameroon. Rapport final Aquatic care. Yaounde, Cameroon.

[47] Duchemin (1998b): «Water and health»: Parameters, quality diagram and practical uses of water for domestic pollution; DAAS Water Classification Guides, Loire-Atlantique, $3 p+$ illustrations. 